OBITUARY

\title{
In memoriam: Roger Reece Stough (1940-2019)
}

\author{
Janet E. Kohlhase ${ }^{1}$
}

Published online: 8 November 2019

(c) Springer-Verlag GmbH Germany, part of Springer Nature 2019

By The Editors: Janet Kohlhase, Martin Andersson and Brian Kim

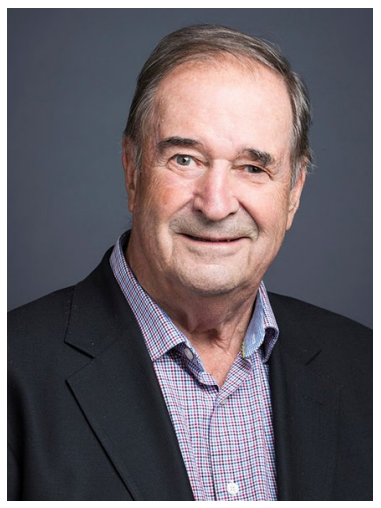

Roger Stough, an eminent Regional Scientist, passed away September 5, 2019. His global presence around the world will be sincerely missed.

Roger had a special impact on the Annals of Regional Science. He served as coeditor-in-chief for over 15 years from 1994 to 2011. During his time at the Annals, the journal grew in prestige and influence. His approach to handling papers still inspires the current set of editors.

Roger's research interests included entrepreneurship and innovation policy, regional economic development, regional economic modeling, transport policy, technology-led regional economic development and institutional barriers to technology deployment.

Roger earned his PhD from Johns Hopkins University and an Honorary Doctorate from Jönköping University in Sweden. He held academic positions at several

Janet E. Kohlhase

kohlhase@Central.UH.EDU

1 Department of Economics, University of Houston, 3623 Cullen Boulevard Room 204, Houston, TX, USA 
universities including his first job at the College of Charleston 1977-1983, followed by Indiana University 1983-1990 and George Mason University 1990-2019. George Mason University named him an Eminent Scholar in 1990 and awarded him a University Professorship in 2013. At George Mason, he served many roles including Director of the Mason Enterprise Center for Entrepreneurship and Regional Analysis and Vice-President for Research and Economic Development.

His research contributions are outstanding and include 45 books (6 with Springer), 85 journal articles and 90 chapters in books. He served on over a dozen editorial boards around the world including the Annals. His research was highly sought-after as he was awarded about $\$ 80,000,000$ in externally funded projects. He often consulted for governments and companies around the globe.

In addition to his service through editing journals, he served in important leadership positions in Regional Science. He was President of the WRSA in 2002 and was elected to be a Fellow of the WRSA. He was active in NARSC and RSAI, serving as President of the RSAI in 2007-2008. In 2008, he was elected to be a Fellow of the Regional Science Association International.

Nevertheless, primarily Roger was a teacher. He inspired generations of students over his 40+ year academic career. As much as all of us will miss him, we also know that through his students he will continue to live on.

Finally, on a personal note, Roger was larger than life in so many ways. His energy and resilience were most impressive. His encouragement to junior scholars, colleagues and friends was boundless. He made us all better, and his passing will leave us all a little emptier.

Publisher's Note Springer Nature remains neutral with regard to jurisdictional claims in published maps and institutional affiliations. 